\title{
PECULIARITIES OF SOCIAL BUSINESS CONCEPT
}

Arturas Simanavicius

Lithuanian Sport University, Lithuania

E-mail: zansim55@gmail.com

Eimantas Kisielius

Lithuanian Sport University, Aland Islands

E-mail: ekisielius@gmail.com

Liliia Kharchevnikova

State Biotechnological University, Ukraine

E-mail: kharchevnikova.lily@gmail.com

Liliya Svorobovych Odesa National Economic University, Ukraine E-mail: lilisvor@gmail.com

Alla Chykurkova State Agrarian and Engineering University in Podilya, Ukraine E-mail: alladomanchuk@gmail.com

Submission: $8 / 8 / 2021$

Accept: 9/20/2021

\section{ABSTRACT}

The essence and uniqueness of social business in solving the most sensitive problems of the society, being able to survive independently and ensure the continuity of activities gives this form of activity an advantage and determines its growing popularity. There are many different definitions of social business. Some authors explain the definition of social business by distinguishing the main aspects that distinguish social business from other forms of activity. However, there are also forms very close to social business. The research objective is to present differences of social business concepts and to identify advantages of such initiatives. The analysis of social business concepts has shown that social business is defined by three principles: social business solves social problems that are not addressed by the public sector; the main motive of social business is public benefit; representatives of social business exploit market mechanisms (without excluding the existing ones) 
INDEPENDENT JOURNAL OF MANAGEMENT \& PRODUCTION (IJM\&P)

http://www.ijmp.jor.br

v. 12, n. 6, Special Edition ISE, S\&P - November 2021

ISSN: 2236-269X

DOI: 10.14807/ijmp.v12i6.1757

when creating social benefits. Research has shown that social business does not yet have one specific definition, but, according to the development and perception of social business, two main directions can be distinguished: Anglo-American and European.

Keywords: social business; social business concept; advantages of social business

\section{INTRODUCTION}

Social business solves problems which cannot be solved by traditional businesses, government agencies, or traditional non-governmental organizations. The essence and uniqueness of social business in solving the most sensitive problems of the society, being able to survive independently and ensure the continuity of activities gives this form of activity an advantage and determines its growing popularity. Such businesses are based on the laws of the market, use proven business principles, are grounded on effective ways to meet the social needs and solve the currently existing societal problems. Social business is associated with such phenomena as social economy and social innovation, and thus social business has been receiving increasing interest from various stakeholders.

Researchers, Kostetska and Berezyak (2014) argue that, for all countries, regardless of their economic or social development, the most important factor for success is the social stability of the society, thus it is necessary to exploit social innovations which manifest themselves through social business. Indeed, social business is expected to integrate business principles into their functioning and adopt an entrepreneurial 'approach' in providing social goods and/or services in order to compete and survive in a demanding and modern market (Borzaga et al., 2014; Piboonrungroj, 2012).

Recent research by researchers around the world (Arantes, Zou \& Che, 2020; Duffield, 2020; Hlatshwayo, 2020; Fathalikhani, Hafezalkotob \& Soltani, 2020; Szczepanska, 2020; Zajda \& Pasikowski, 2020) show that, in cases of disasters, crises, pandemics, social business in cooperation with various structures and organizations can contribute to solving various problems because social entrepreneurship fosters social cohesion (e.g., it employs vulnerable people, ensures equality - in many social business enterprises, women are managers and board members), and increases the social capital (social business builds trust, it solves problems that public authorities or traditional enterprises have previously failed to deal with), which creates new opportunities for employment and integration into the labor market; it also complements the provided public services (those municipalities which are looking for ways how to serve their people should include social businesses as partners). Social business 
INDEPENDENT JOURNAL OF MANAGEMENT \& PRODUCTION (IJM\&P)

http://www.ijmp.jor.br

v. 12, n. 6, Special Edition ISE, S\&P - November 2021

ISSN: 2236-269X

DOI: 10.14807/ijmp.v12i6.1757

is valued for its contribution to the economic and social well-being and its ability to cope innovatively with social challenges.

\section{LITERATURE REVIEW}

\subsection{Theoretical justification of social business}

There are many different definitions of social business. Some authors focus on the interpretation of the definition of social business by distinguishing among the main aspects that distinguish social business from other forms of activity. However, there are also forms that are particularly close to social business. Some authors identify them specifically, whereas others say that they are only forms of different levels.

The analysis of social business concepts shows that three principles are most commonly used in social business definitions:

a) Social business tackles social/environmental problems that the public sector and the free market cannot solve;

b) The essential motif of social entrepreneurship is social benefit;

c) Social entrepreneurs usually operate by exploiting (rather than rejecting) market mechanisms.

It has been found that social business does not yet have one specific definition. Research has shown that social business can take many forms, but it differs from the traditional business model in that its primary mission is to have a social impact and yield benefit to the society - by reducing or mitigating sensitive social problems or market failures - rather than by maximizing the shareholder profits. The earned profit is primarily used to achieve social goals, i.e., it is reinvested in the development of its activities or used for social and/or charitable activities. Poor understanding of social business leads to a critical and negative attitude towards such initiatives, and, instead of support, they receive restrictive criticism.

Social business undoubtedly has positive aspects, as evidenced by the growing interest, EU funding, the abundance of research from academia and the diversity of practice initiatives. When creating a social business, social entrepreneurs solve social problems in a sustainable way. The solution to any social problem definitely benefits the target group, and, at the same time, the society as a whole. Although such initiatives are initiated on a small scale, social business, according to Santos (2012), addresses important social issues in the global context, although it only starts at the regional level. 
In solving social problems, such a business creates value that different scholars examine through different prisms. Creating value for such a business, according to Driver (2012), is the basis for major change and leads to a completely different understanding of capitalism.

The benefits for one specific type of organization are seen by Dees (2007) - NGOs in finding innovative, sustainable sources of funding for their activities through social business activities.

Researchers highlight the following benefits of social business for the society:

a) creates new, long-term jobs;

b) promotes more sustainable business;

c) increases the country's economic competitiveness;

d) reduces the state budget for social benefits;

e) promotes smart growth through social innovation;

f) promotes social cohesion;

g) reduces social exclusion, inequality and environmental problems.

However, social businesses face difficulties in measuring the benefits they generate. It is common for traditional for-profit businesses to use tangible numbers and rely on a variety of financial indicators, but, according to Austin, Stevenson, Wei-Skillern (2006), social businesses have to use complex and sometimes temporary calculation methods. In their view, it is very difficult to assess the impact and results in the social sector, and, even if some methods had been developed to measure results, the real organizational impact would be long-term and difficult to assess.

For this reason, a number of measurement methods are accepted in the scientific literature while considering the different characteristics, activities and objectives of organizations and the aspects to be assessed. Economic efficiency analysis, cost-benefit analysis, social return on investment are traditionally used to calculate the social impact. Recently, however, the social return on investment (SROI) methodology has been promoted more as a holistic approach to the social impact assessment.

Initially, the social impact assessment methodology was intended as a social impact assessment methodology for the preparation of environmental impact assessment reports. However, researchers (Guclu, 2002; Huda, 2016; Kiss, 2019; Mair, 2006), and practitioners (Borgazo, 2020; Bosma, 2018) currently apply social impact assessment methodologies to 
analyze, monitor processes, plan the social consequences of interventions, and justify aspects of social development.

According to researchers (Esteves, 2012), the benefits of improved social impact assessment and management processes for business are now widely recognized and include:

- greater certainty of project investment and greater probability of project success;

- reduction of social and environmental risks and conflicts faced by industry and communities;

- better capacity for early identification of problems and therefore reduction of costs and unavoidable costs through cost-effectiveness assessment and project planning;

- improved social and physical infrastructure planning;

- the process of informing and involving internal and external stakeholders and helping to build trust and a mutually beneficial future;

- improved quality of life for workers and better attraction and retention of skilled workers;

- positive legacy not only during the project;

- increased competitive advantage due to superior social performance and increased company reputation.

\subsection{The concept of social business}

There are many different definitions of social business. Some authors explain the definition of social business by distinguishing the main aspects that distinguish social business from other forms of activity. However, there are also forms very close to social business. Some authors identify them, others argue that these are just forms at different levels. This section discusses the links and dimensions of social business and other business phenomena such as social enterprises.

The phenomenon of social business emerged only after welfare states and mixed economic systems were engulfed in crisis situations. Research focuses on the uniqueness of this business in terms of operating principles (Šalkauskas \& Dzemyda, 2013; Kvieska, 2015), social business models (Kuklytė \& Vveinhardt, 2016; Yunus, Moingeon \& Lehmann-Ortega, 2010; Pol \& Ville, 2009).

Šalkauskas (2013) states: "Social business is a form of business in which the social mission of an organization is carried out together with economic activity. Such an 
INDEPENDENT JOURNAL OF MANAGEMENT \& PRODUCTION (IJM\&P)

http://www.ijmp.jor.br

v. 12, n. 6, Special Edition ISE, S\&P - November 2021

ISSN: 2236-269X

DOI: 10.14807/ijmp.v12i6.1757

organization applies private sector approaches to public sector goals and is able to fully sustain itself in its commercial activities. Social business is a business whose innovative activity or structure (including ownership) is used to create a certain social network in the course of economic activities, i.e. y. the supply of goods, the manufacture of products or the provision of services."

Kvieska (2015) defines social business as a process in which organizations use innovative entrepreneurial solutions and contribute to or initiate projects for the well-being of society.

Kuklyte and Vveinhardt (2016) links the origins of social business to the existing form of traditional business, where improvements are made and the business is adapted to create economic value based on social impact. According to this concept of social business, the principles of management of organizations operating in the private sector are used, which help to achieve the goals of the public sector by conducting commercial activities and creating social value for the society.

Social business, according to Navasaitienè (2017), as a business model, using the market mechanism, seeks profit related to social goals and follows the provisions of socially responsible business. It is created in an effort to fill a niche that cannot be filled by a public service. The definition of a socially responsible company is generally understood in such a way that the managers of these companies voluntarily follow social and environmental principles, the company's own ideology is focused on close cooperation with the community, local authorities and attention to socially sensitive (vulnerable) groups.

Social business is perceived as directly related to society and living conditions in it. Therefore, when interpreting which companies may belong to the category of social entrepreneurship, the so-called non-governmental organizations (NGOs) dealing with social problems first come to the fore, and this is usually associated with the terms "non-profit", "voluntary", "non-governmental" associations; public institutions; specific non-profit organizations (Markaitienè, 2018).

Ridley-Duff and Bull (2011) described social business in detail and pointed to the place of social business in the business environment. Researchers Alter (2007), Defourny (2001), Martin, and Osberg (2007)) have extensively analyzed social business and discussed how it should be perceived. Other researchers (Guclu et al., 2002; Perrini \& Vurro, 2006; Sommerrock, 2010) have examined the functioning of the social business model. However, 
INDEPENDENT JOURNAL OF MANAGEMENT \& PRODUCTION (IJM\&P)

http://www.ijmp.jor.br

v. 12, n. 6, Special Edition ISE, S\&P - November 2021

ISSN: 2236-269X

DOI: 10.14807/ijmp.v12i6.1757

the presented analysis of the perception of social business and the mechanism of operation of the social business model lacked completeness, the essential components of the social business model were not singled out.

According to Yunus (2010), social business is a new type of enterprise and it differs from traditional forms of enterprise organization, the main goal of which is to maximize profits. The researcher describes two types of social business, two forms of organization or management that would distinguish "pure" social business from other businesses that may currently acquire the term "social". According to the researcher, there are two main types of social business.

Yunus (2010) points out that the first type of social business is described as an enterprise in which income and costs are balanced, there are no losses and dividends that are devoted to solving a social problem. The owners of such companies are investors, they invest profits by expanding and strengthening the business (Yunus, 2010). In such a business, investors could anticipate the period within which they would withdraw the amount invested.

Wildmannova (2018) points out that the concept of social business is based on publicprivate partnerships in the provision of public services and the promotion of public employment policies.

The European Commission (2013) provides the following definition of a social enterprise: "A social enterprise is a social economy entity whose main purpose is to have a social impact and not to make a profit for its owners or shareholders. It operates by providing goods and services to the market on the principles of entrepreneurship and innovation, and uses its profits primarily to achieve social goals. It shall be managed in an open and accountable manner, in particular involving employees, consumers and stakeholders affected by its commercial activities. "This definition shows that the social economy in particular is a good example at the micro level and that market economy principles rather than making a profit. Social business is based primarily on the entrepreneurial aspect, that there is a regular economic activity, which is defined by various indicators - what is the share of market revenue and paid labor, and what is the share of volunteering. The second aspect of the social goal states that the primary motive of the activity is a clear social goal, which distinguishes social business from traditional businesses and is measured by the following indicators: how many activities are aimed at ensuring social benefits and which target groups are focused on social problems. 
INDEPENDENT JOURNAL OF MANAGEMENT \& PRODUCTION (IJM\&P)

http://www.ijmp.jor.br

v. 12, n. 6, Special Edition ISE, S\&P - November 2021

ISSN: 2236-269X

DOI: 10.14807/ijmp.v12i6.1757

Table 1: Development of social business concepts

\begin{tabular}{|c|c|c|}
\hline Author & Year & Social business perception \\
\hline $\begin{array}{l}\text { Melo Neto and } \\
\text { Froes }\end{array}$ & 2002 & $\begin{array}{l}\text { They believed that social entrepreneurship was created with the aim of creating a link } \\
\text { between human, social and sustainable development in communities. }\end{array}$ \\
\hline Cruz & 2006 & $\begin{array}{l}\text { Perceptions of social business are still being developed. However, most social movements } \\
\text { operated by individuals and business groups with the sole goal of improving the lives of } \\
\text { the poor. }\end{array}$ \\
\hline Mair and Marti & 2006 & $\begin{array}{l}\text { Social entrepreneurship is a process that involves the combination of innovative tools and } \\
\text { resources to seek opportunities to bring about social change and / or meet social needs. }\end{array}$ \\
\hline Robinson & 2006 & $\begin{array}{l}\text { Social entrepreneurship is defined as a process that involves the identification of a specific } \\
\text { social problem and its appropriate solution. This process includes the assessment of the } \\
\text { social impact of companies, the business model and sustainability, as well as the } \\
\text { development of a profit-oriented or non-profit social mission, always considering social } \\
\text { sustainability. }\end{array}$ \\
\hline Novaes and Gil & 2009 & $\begin{array}{l}\text { Social entrepreneurship is a process that encourages greater participation in local } \\
\text { entrepreneurship by strengthening people's connection to their city, land and culture. }\end{array}$ \\
\hline Yunus & 2010 & $\begin{array}{l}\text { Social business is a business that focuses on the social cause. The purpose of a business is } \\
\text { to achieve one or more social goals through the activities of the company. Investors do not } \\
\text { want any personal benefit. }\end{array}$ \\
\hline Nicholls & 2010 & $\begin{array}{l}\text { Social entrepreneurship is understood as the process of changing the supply of public } \\
\text { goods and social / environmental services. }\end{array}$ \\
\hline Campos et al. & 2012 & $\begin{array}{l}\text { Social enterprises tend to operate in situations where the primary competence to act and } \\
\text { decisions lies with government agencies. }\end{array}$ \\
\hline Rosolen et al. & 2012 & $\begin{array}{l}\text { The concept of social entrepreneurship is embedded in the creation of social value and in } \\
\text { the question of what innovative methodology, services or products to choose to bring about } \\
\text { social change. }\end{array}$ \\
\hline $\begin{array}{l}\text { European } \\
\text { Commission }\end{array}$ & 2013 & $\begin{array}{l}\text { A social enterprise is a social economy entity whose main purpose is to have a social } \\
\text { impact and not to make a profit for its owners or shareholders. It operates by providing } \\
\text { goods and services to the market on the principles of entrepreneurship and innovation, and } \\
\text { uses its profits primarily to achieve social goals. It shall be managed in an open and } \\
\text { accountable manner, in particular involving employees, consumers and stakeholders } \\
\text { affected by its commercial activities. }\end{array}$ \\
\hline Šalkauskas & 2013 & $\begin{array}{l}\text { Social business is a form of business in which the social mission of an organization is } \\
\text { carried out in conjunction with economic activity. Such an organization applies private } \\
\text { sector approaches to public sector goals and is able to fully survive in commercial } \\
\text { activities. Social business is a business whose innovative activity or structure (including } \\
\text { ownership) is used to create a certain social network in the course of economic activities, } \\
\text { i.e. y. the supply of goods, the manufacture of products or the provision of services. }\end{array}$ \\
\hline Kvieska & 2015 & $\begin{array}{l}\text { Social business is a process in which organizations use innovative entrepreneurial solutions } \\
\text { and contribute to or initiate projects for the benefit of society. }\end{array}$ \\
\hline $\begin{array}{l}\text { Social business } \\
\text { concept }\end{array}$ & 2015 & $\begin{array}{l}\text { Social business is a business model that, using the market mechanism, links profit-making } \\
\text { to social goals and priorities, is based on the provisions of socially responsible business } \\
\text { and public-private partnerships, and applies social innovation. }\end{array}$ \\
\hline $\begin{array}{l}\text { Kuklyte and } \\
\text { Vveinhardt }\end{array}$ & 2016 & $\begin{array}{l}\text { The origins of social business are linked to the existing form of traditional business, where } \\
\text { improvements are made and the business is adapted to create economic value based on } \\
\text { social impact. }\end{array}$ \\
\hline Navasaitienè & 2017 & $\begin{array}{l}\text { Social business as a business model, using the market mechanism, seeks profits related to } \\
\text { social goals and follows the provisions of socially responsible business. Developed in an } \\
\text { effort to fill a niche that cannot be filled by a public service. }\end{array}$ \\
\hline Wildmannova & 2018 & $\begin{array}{l}\text { The concept of social business is based on public-private partnerships in the provision of } \\
\text { public services and the promotion of public employment policies. }\end{array}$ \\
\hline
\end{tabular}


DOI: 10.14807/ijmp.v12i6.1757

Pučetaite et al. 2019 The narrow concept of social business treats social business as an actor in the nongovernmental sector that applies business principles to make a profit. In a broad sense, social business is an organization operating in any sector, which presupposes the unmet needs of the private and public sectors.

The aspect of social business management is also singled out when explaining what mechanisms ensure the implementation of social goals and how limited profits are distributed.

It is observed that social business does not have one specific definition, but according to the development and perception of social business, two main directions can be distinguished:

- Anglo-American;

- European.

The range of definitions of social business in the Anglo-American direction is quite wide: from non-profit companies with a social mission to those whose main axis is social innovation. According to Monzon and Chaves (2012), English and American social business models are characterized by different currents, so the field of social business is defined differently. Some social enterprises consider social enterprises to be non-profit organizations pursuing a social goal, while others classify as such enterprises which, according to Campos (2012), are "related to social innovation and the satisfaction of social needs and the form of ownership of the enterprise is irrelevant. private capitalist or in line with the European concept of the social economy). Continental European traditions are based on three dimensions that characterize social business: social, entrepreneurial and managerial”.

Monzon (2012) points out that, according to the traditions of continental Europe, "enterprises are the result of collective entrepreneurship in the social economy". Under the Social Business Initiative, the European Commission classifies social enterprises in the social economy subsector as key socio-economic actors.

On the other hand, when analyzing how researchers perceive social business, it is important to review how social business is perceived in individual countries and what commonalities and differences emerge in defining social business.

\subsection{Differences of social business from other activity phenomena}

There is an opinion that social business is not the same as social enterprises (Šalkauskas \& Dzemyda (2015)). Looking at the definition of a social enterprise, it shows that most enterprises are socially oriented, generate income, their main activity is targeted at a 
INDEPENDENT JOURNAL OF MANAGEMENT \& PRODUCTION (IJM\&P)

http://www.ijmp.jor.br

v. 12, n. 6, Special Edition ISE, S\&P - November 2021

ISSN: 2236-269X

DOI: 10.14807/ijmp.v12i6.1757

certain section of society, the form itself is diverse, employment relationships are often voluntary, organizations can be non-profit or for-profit, but reinvesting in development may also receive support (Institute for SME Research and TSE Entre, Turku School of Economics, 2007). Although all the elements singled out are related to social business as well, Thompson (2006) argue that social initiatives can arise both in social business and in a completely different form of social enterprise.

According to Yunus (2008), social business is one of the components of social entrepreneurship and those who create and manage such businesses are social entrepreneurs, but not all of them engage in such activities in the form of social business. According to Yunus (2008), social business aims to meet the needs of highly deprived consumers from developing countries and is also different from social enterprise as a form based on social initiatives.

The differences and concepts of these phenomena were presented by Pagirys (IESEC, 2010) at the conference "Challenge: Social Entrepreneurship" he stated that there are many different definitions and concepts of social business, therefore it is necessary to distinguish social business from other phenomena. They are presented in table 2 .

Table 2: Characteristics of social business

\begin{tabular}{|l|l|}
\hline Social business is an organization that: & Social business is different from: \\
\hline $\begin{array}{l}\text { offers a new product or service that } \\
\text { meets the needs of low-income people, }\end{array}$ & $\begin{array}{l}\text { corporate social responsibility, based on } \\
\text { supplies products or services in an } \\
\text { accessible form to low-income people } \\
\text { to meet their needs; }\end{array}$ \\
$\begin{array}{l}\text { to social activities, } \\
\text { innovative in the process of involving } \\
\text { socially vulnerable groups, }\end{array}$ & $\begin{array}{l}\text { traditional non-governmental organizations } \\
\text { (NGOs), which have other sources of funding, are } \\
\text { not integrated with social impact, }\end{array}$ \\
$\begin{array}{l}\text { creates a sustainable model that enables } \\
\text { society to benefit from business, } \\
\text { has the potential to expand or replicate, } \\
\text { Income-generating activities are } \\
\text { integrated with social impact creation. }\end{array}$ & $\begin{array}{l}\text { green business organizations whose initiatives, } \\
\text { product or service have a positive impact on the } \\
\text { environment but not on social impact, }\end{array}$ \\
& $\begin{array}{l}\text { Traditional businesses that focus on the needs of } \\
\text { the lowest income earners, but whose main goal is } \\
\text { higher profits rather than meeting the needs of } \\
\text { society. }\end{array}$ \\
\hline
\end{tabular}

Source: created by IESEC, 2010.

Examining how social business differs from more well-known and older phenomena such as corporate social responsibility, traditional business or non-governmental organizations, it is possible to better understand social business itself. 
INDEPENDENT JOURNAL OF MANAGEMENT \& PRODUCTION (IJM\&P)

http://www.ijmp.jor.br

v. 12, n. 6, Special Edition ISE, S\&P - November 2021

ISSN: 2236-269X

DOI: 10.14807/ijmp.v12i6.1757

It should be noted that other authors also confirm Table 2 indicated differences. For example, Maniokas (2014) also singles out social responsibility, which, in his view, is only an ancillary activity typical of traditional businesses that can afford it for sufficient profit.

How to distinguish social business from other forms of organizations advises Bozek (2009). Using the spectrum of social and financial returns, the presented model distinguishes social businesses in comparison with other forms of organizations.

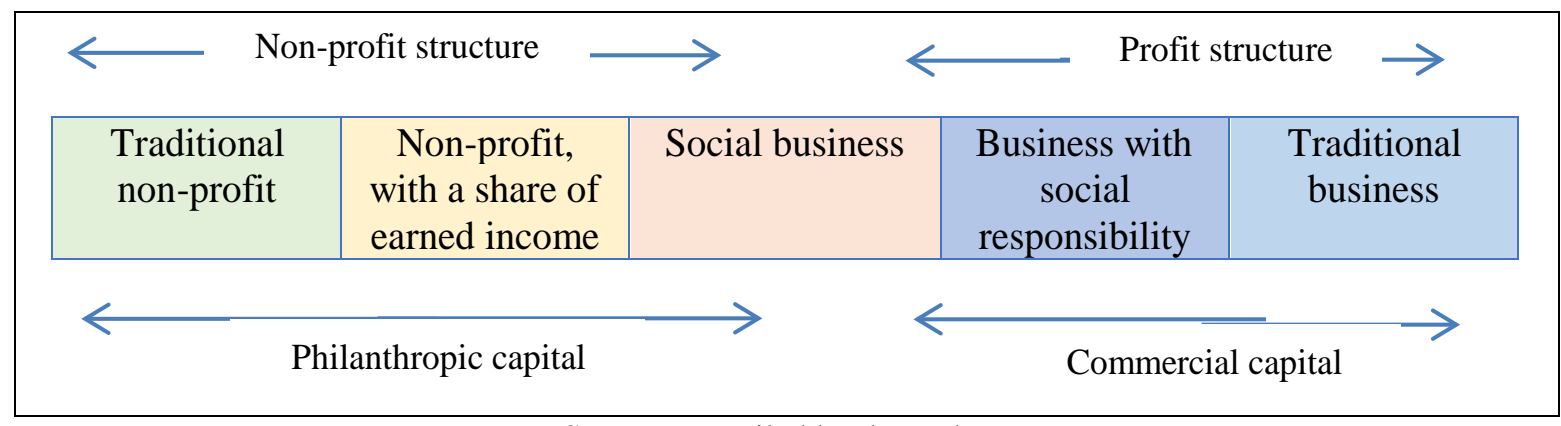

Source: compiled by the authors

The spectrum of financial returns presented in the first figure helps to distinguish traditional business from social, traditional non-profit organizations. This is confirmed by Maniokas (2014), who argues that the goal of social businesses is related to the benefits to society and another major difference from traditional businesses is that profits are invested in business development. There are also those who contradict the opinion that traditional businesses stand out for their motivation to make only a profit and make money for shareholders.

According to Martin and Osberg (2010), traditional business also has a vision and pursues a certain mission. The authors present a possible solution for distinguishing traditional business from social - through value proposition. Traditional businesses seek to meet an existing need when demand and at the same time profit are secured, and social businesses provide value, no matter how low the demand is, lack of money for the target group, but a significant impact on this group.

Luke and Chu (2013) presents the differences between social business and non-profit organizations or traditional businesses, pointing out that social business is linked to a strategy that ensures financial stability, usually innovations that address unresolved social problems and thus create social change. value to society. 
Santos (2012) argues that social business seeks long-term solutions suitable for solving social problems, while traditional business has the goal of gaining long-term competitive advantage.

There is another view that there is no need to compare different phenomena. Tukamushaba, Orobia and George (2011) argue that traditional business is not the opposite of social and has commonalities and similarities, only the percentage distribution of social or economic aspirations in these forms of organizations differs.

However, saying that social business differs from other forms and types of activity, such as social enterprise, corporate social responsibility, or green business, allows the scope to be understood and defined more precisely, which is precisely necessary for further research.

Social business certainly has its positive aspects, as evidenced by the growing interest, EU funding, the abundance of research from the academic community and the diversity of practice initiatives.

When creating a social business, social entrepreneurs take on social problems in a sustainable way. The solution to any social problem definitely benefits the target group and, at the same time, society as a whole.

Although such initiatives are still scarce, social business, according to Santos (2012), addresses important social issues in a global context, albeit only at a regional level. In solving social problems, such a business creates value that is examined by different scholars from different perspectives.

Creating value for such a business, according to Driver (2012), is the basis for major change and leads to a completely different understanding of capitalism.

Dees (2007) sees benefits for one specific type of organization, non-governmental organizations, which can find innovative, sustainable sources of funding for their activities through social business activities.

When analyzing the benefits of social business or its positive aspects, researchers first single out the components of the social business model. According to Anacleto et al. (2017), social business is characterized by: 
- Impact of social profit: Unlike financial profit, social profit measures the impact of social business on society. Basically, business will be good for society. Environmental profit is another feature under consideration if social business also benefits the ecosystem.

- Social value: the development of products and services to provide social value not only to customers but also to stakeholders, as all such countries are included in the social business model. Another approach is who the products / services will be for and who the beneficiaries will be.

- Value creation: Internal and external value chains must be established and operational to create and deliver this value to target customers, which is the production and delivery of products / services, respectively. This includes available resources and relationships with partners and suppliers.

- Financial profit: this describes the need for a cost structure, maximizing the revenue generated by using the products / services and their respective values, and the recovery of capital employed so that the profitability results have to be reinvested in the business itself.

Other researchers (Jablonski, 2019) suggest that trust can be a component that can be used to develop effective social business models. And it is precisely the benefits created by social business that are described as the greatest positive impact of social business.

\section{CONCLUSIONS AND RECOMMENDATIONS}

The analysis of social business concepts has shown that social business is defined by three principles:

- $\quad$ social business solves social problems that are not addressed by the public sector;

- the main motive of social business is public benefit;

- representatives of social business exploit market mechanisms (without excluding the existing ones) when creating social benefits.

Research has shown that social business does not yet have one specific definition, but, according to the development and perception of social business, two main directions can be distinguished: Anglo-American and European. Some representatives of social business consider non-profit organizations pursuing a social goal as social enterprises. Others classify companies in this area only those that are related to meeting social needs. In this case, the form of ownership of the company is irrelevant to them. Continental European traditions are 
INDEPENDENT JOURNAL OF MANAGEMENT \& PRODUCTION (IJM\&P)

http://www.ijmp.jor.br

v. 12, n. 6, Special Edition ISE, S\&P - November 2021

ISSN: 2236-269X

DOI: 10.14807/ijmp.v12i6.1757

based on three dimensions that characterize social business: social, entrepreneurial and managerial.

The analysis allowed to refine the concept of social business and show different interpretations of its perception in different countries. Research has shown that social business can operate in a variety of forms, but differences in social business from the traditional business model have been identified. Research has shown that social business solves sensitive social problems without seeking to increase shareholder profits, so most of the profits earned are spent primarily on solving social problems, i. y. reinvested in the development of its activities or used for social, charitable activities. The scope of social business has been refined.

Research has shown that researchers are debating the benefits of social business. Social businesses face difficulties in assessing the benefits they create. It's easy for traditional for-profit businesses to use tangible numbers and rely on a variety of financial metrics, but social businesses have to use complex and sometimes temporary calculation methods. Studies have revealed that it is very difficult to assess impact and outcomes in the social sector. Even if methods were developed to measure results, the real organizational impact would be longterm.

Researchers are now faced with many vague concepts, tools, and methods for purposes other than measuring the impact of social business. For this reason, a number of measurement methods are found in the scientific literature, taking into account the different characteristics, activities and objectives of organizations and the aspects to be assessed.

\section{REFERENCES}

Alter, A. L., Oppenheimer, D. M., Epley, N., \& Eyre, R. N. (2007). Overcoming Intuition: Metacognitive Difficulty Activates Analytic Reasoning. Journal of Experimental Psychology, 136(4), 569-576. DOI: 10.1037/0096 3445.136.4.569.

Anacleto, K. C. O., Paiva, R. V. C., \& Moura, L. R. C. (2017). Propolis Project: Development of a Social Business Model Proposal. Revista Eletrônica de Estratégia \& Negócios, 10(3), 27-46. DOI: 10.19177/reen.v10e3201727-46.

Arantes, V., Zou, C., \& Che, Y. (2020). Coping with waste: A government-NGO collaborative governance approach in Shanghai. Journal of Environmental Management, 259 (1).

Austin, J., Stevenson, H., \& Wei-Skillern, J. (2012). Social and commercial entrepreneurship: same, different, or both? Revista de Administração, 47(3), 370-384. 
Borzaga, C., Galera, G., Franchini, B., Chiomento, S., Nogales, R., \& Carini, C. (2020). Social enterprises and their ecosystems in Europe - Comparative synthesis report. https://ec.europa.eu/social/main.jsp?catId=738\&langId=en\&pubId=8274\&furtherPubs=yes.

Bosma, N. (2018). Social enterprises and their ecosystems in Europe. Country report. The Netherlands. https://www.euricse.eu/social-enterprises-and-their-ecosystems-in-europemapping-study/netherlands.pdf.

Campos, J. L. M., Spear, R., \& Frobel, L. (2012). The social economy in the European Union. No. CESE/contract CES, 18-106

Cruz, G. (2013). As Duas Faces do Empreendedorismo Social. Revista Eletrônica do Mestrado em Administração da Universidade Potiguar - RAUnP, 5(1), 9-20.

Dees, J. G., \& Anderson, B. B. (2007). Sector-Bending: Blurring Lines Between Nonprofit and ForProfit. Society, 40(4), 16-27.

Defourny (2010). Conceptions of Social Enterprise and Social Entrepreneurship in Europe and the United States: Convergences and Divergences. Journal of Social Entrepreneurship. $1(1), 32-53$.

Driver (2012). Social Enterprise in Europe: Recent Trends and Developments. EMES Working Paper, 08:01

Duffield, M. (2020). Human security: linking development and security in an age of terror. Relaciones internacionales-Madrid, 43(1), 11-32.

Esteves, A. M., Franks, D. \& Vanclay, F. (2012). Social impact assessment: the state of the art. Impact Assessment and Project Appraisal, 30(1), 34-42.

European Commission (2013). Social economy and social entrepreneurship. Social Europe guide, 4. Source:

http://www.sofisam.se/download/18.3453fc5214836a9a472a0430/1472023483855/EU\%20ko mmissionen,\%20Social\%20Economy\%20and\%20Social\%20Entreprenreurship.pdf.

Fathalikhani, S., Hafezalkotob, A., \& Soltani, R. (2020). Government intervention on cooperation, competition, and coopetition of humanitarian supply chains. Socio-Economic Planning Sciences, 69 (1).

Guclu, A., Dees, J. G., \& Anderson, B. B. (2002) The process of social entrepreneurship: creating opportunities worthy of serious pursuit. Durham, NC: Center for the Advancement of Social Entrepreneurship, Fuqua School of Business, Duke University.

Hlatshwayo, M. (2020). Workers' education under conditions of precariousness: Reimagining workers' education. Economic and Labour Relations Review, 31 (1), 96-113.

Huda, M., \& Islam, A. (2016). Social business: meaning, scope, and evaluation. Global Marketing Conference at Hong Kong Proceedings, 1262-1281.

Jablonski, A., \& Jablonski, M. (2019). Trust as a Key Factor in Shaping the Social Business Model of Water Supply Companies. Sustainability Volume: 11 Issue: 20 Article Number: 5805 DOI: 10.3390/su11205805.

Kiss, J., \& Mihaly, M. (2019). Social enterprises and their ecosystems in Europe. Country report. Hungary.

Kostetska, I., \& Berezyak, I. (2014). Social Entrepreneurship as an Innovative Solution Mechanism of Social Problems of Society. Management Theory \& Studies for Rural Business \& Infrastructure Development, 36(2/3), 569-577. 
Kuklytė, J., \& Vveinhardt, J. (2016). Kuriamos socialinès vertès maksimizavimas: socialinių verslo modelių taikymo Lietuvoje tendencijos. Organizacijų vadyba: sisteminiai tyrimai (77).

Kvieska, V. (2015) Socialinio verslo ir verslumo kompetencijų sąsajos. Socialinis ugdymas/ Sumanioji edukacija, 41(2), 64-78.

Mair, J., \& Marti, I. (2006). Social entrepreneurship research: A source of explanation, prediction, and delight. Journal of world business, 41.1, 36-44.

Markaitienè, A. (2018). Socialinis verslas kaime: sąlygos pradėti ir galimybės vystyti.

Straipsnių rinkinys, Lietuvos kaimo vietovių konkurencingumo stiprinimas: geroji patirtis“. Akademija

Martin, R., \& Osberg, S. (2007). Social entrepreneurship: The case for definition. Stanford Social Innovation Review, Spring. Retrivied from http://www.ssireview.org/articles/entry/social_entrepreneurship_the_case_for_definition. Access: May 2, 2021.

Melo Neto, F. P., \& Froes, C. (2002). Empreendedorismo social: a transição para a sociedade sustentável. Rio de Janeiro: Qualitymark.

Monzón, J. L. \& Chaves, R. (2012). The social economy in the European Union. Présentation, CIRIEC.

Navasaitienè, S. (2017). Socialinio verslo iniciatyvos kaimo bendruomenėse. Tarptautinė mokslinė-praktinė konferencija „Žemès ūkio gamintojų organizacijų ir kooperacijos plètros galimybès ir priemonès ES valstybèse”.

Nicholls, J., Lawlor, E., Neitzert, E., \& Goodspeed, T. A (2012). Guide to Social Return on Investment. 2nd ed. London: The Cabinet Office. Retrieved from

http://www.bond.org.uk/data/files/Cabinet_office_A_guide_to_Social_Return_on_Investmen t.pdf. Access: 08 March 2021.

Novaes, M. B. C., \& Gil, A. C. (2009). A pesquisa-ação participante como estratégia metodológica para o estudo do empreendedorismo social em administração de empresas.

Revista de Administração Mackenzie, 10(1), 134-160.

Perrini, F., \& Vurro, C. (2006). Social Entrepreneurship: Innovation and Social Change Across Theory, and Practice. In: Mair, J., Robinson, J., and Hockerts, K. (Eds.). Social Entrepreneurship. New York: Palgrave-MacMillan, pp. 57-85.

Piboonrungroj, P. (2012). Understanding Social Enterprise: Theory and Practices. International Journal of Entrepreneurial Behavior \& Research, 18(6), 743-745.

Pol, E., \& Ville, S. (2009). Social innovation: Buzz word or enduring term. The Journal of Socioeconomics, 38, 878-885.

Pušinaitè-Gelgotė, R., Pučetaitè, R., \& Novelskaite, A. (2019). Socialinio verslo poveikių vertinimo patirtys Lietuvoje socialinių verslinink(i)ų požiūriu. Informacijos mokslai, 86, 116-132.

Ridley-Duff, R., \& Bull, M. (2011). Understanding Social Enterprise: Theory and Practice. Business \& Economics.

Robinson, J. (2006). Navigating social and institutional barriers to markets: How social entrepreneurs identify and evaluate opportunities. In: Social entrepreneurship. Palgrave Macmillan, London, p. 95-120. 
Rosolen, T., Tiscoski, G. P., \& Comini, G. M. (2014). Empreendedorismo social e negócios sociais: um estudo bibliométrico da publicação nacional e internacional. Revista Interdisciplinar de Gestão Social, 3(1), 85-105.

Šalkauskas, Š., \& Dzemyda, I. (2013). Socialinio verslo modelis. Verslo sistemos ir ekonomika, 3(2), 208-219.

Santos, F. M. (2012). A positive theory of social entrepreneurship. Journal of business ethics, 111.3, 335-351. Retrivied from https://sites.insead.edu/facultyresearch/research/doc.cfm?did=41727. Access: June 14, 2021. Sommerrock, K. (2010). Social entrepreneurship business models: incentive strategies to catalyze public goods provision. New York: Palgrave Macmillan.

Szczepanska, K. (2020). NGO Capacity Building in the Wake of Japan's Triple Disaster of 2011: The Case of the TOMODACHI NGO Leadership Programme (TNLP). Asian Studies Review. DOI: 10.1080/10357823.2020.1720600.

Thompson, J., \& Doherty, B. (2006). The diverse world of social enterprise: A collection of social enterprise stories. International Journal of Social Economics, 33(5/6), 399-410.

Tukamushaba, E. K., Orobia, L., \& George, B. P. (2011). Development of a conceptual model to understand international social entrepreneurship and its application in the Ugandan context. Journal of International Entrepreneurship, 9(4), 282-298.

Wildmannova, M. (2018). Barriers and Opportunities for the Development of Social Entrepreneurship: Case Study of Czech Republic. Journal of Economic and Social Development, 5(1), 51-57.

Yunus, M., Moingeon, B., \& Lehnmann-Ortega, L. (2010). Building social business models: Lessons from the Grameen experience. Long range planning, 43.2, 308-325. Retrieved from http://www.hec.fr/var/corporate/storage/original/application/4c2fc23d0007ff24248fc6f8003d 468d.pdf. Access: 02 March 2021.

Zajda, K. K., \& Pasikowski, S. (2020). Traits of Leaders of Rural Non-governmental Organisations as Predictors of Collaboration Between NGOs and Rural Gmina Offices: Voices from Central Poland, 31(2), 345-358. 